\title{
Inhibition of namnam (Cynometra cauliflora L.) leaves extract on the growth of Porphyromonas gingivalis
}

\author{
Zakiyya Ulpiyah ${ }^{1}$ Amandia Dewi Permana Shita ${ }^{1 *}$, Melok Aris Wahyukundari² $^{2}$ \\ 'Department of Biomedics, Faculty of Dentistry University of Jember, Indonesia \\ ${ }^{2}$ Department of Periodontics, Faculty of Dentistry University of Jember, Indonesia
}

\begin{abstract}
Introduction: Porphyromonas gingivalis growth should be prevented to minimise inflammation in periodontal tissues. Antibacterial herbs need to be considered because there are side effects caused by synthetic antibacterial drugs. Namnam (Cynometra cauliflora L.) leaves are known for having antibacterial effects. The purpose of this research was analysing the inhibition potential, and the highest inhibition concentration of namnam leaves extract on the growth of Porphyromonas gingivalis. Methods: 24 samples were divided into 6 groups. The positive control group was given $0.2 \%$ chlorhexidine, and the treatment group was given various concentrations $(100 \%, 80 \%, 60 \%, 40 \%$, and $20 \%)$ of namnam leaves extract. The disc which spilled by various concentrations of namnam leaves extracts and $0.2 \%$ chlorhexidine was placed on a medium which has been inoculated by $P$. gingivalis, then incubated at $37^{\circ} \mathrm{C}$ for 48 hours. The inhibition zone was measured using a vernier calliper. Results: The concentration of $100 \%$ had the highest average inhibition zone value, which was $11.43 \mathrm{~mm}$. The content in namnam leaves extracts which serve as antibacterial were tannins, flavonoids, triterpenoids, saponins and quinones. Conclusion: Namnam leaves extract can inhibit the growth of $P$. gingivalis. $100 \%$ of namnam leaves extract has the highest antibacterial inhibition zone.
\end{abstract}

Keywords: Antibacterial, namnam leaves extract, periodontal disease, Porphyromonas gingivalis

p-ISSN 1979-0201; e-ISSN 2549-6212; Available from: http://jurnal.unpad.ac.id/pjd/article/view/18540

DOI: $10.24198 /$ pjd.vol30no3.18540

Submission: Sep 02, 2018; Accepted: Jun 18, 2019; Published online: Jul 31, 2019

\section{INTRODUCTION}

Prevalence of dental and oral health problems are still relatively high $(25.9 \%) .{ }^{1}$ One of the most prevalent disease in the community is periodontal disease. Household Health Survey in 2012 results show that periodontal disease ranks second with a prevalence of $\pm 70 \%$ of Indonesian population. ${ }^{1}$
Periodontal disease is the result of a complex interplay between subgingival biofilms and body immune cells that cause inflammation in the periodontal tissues in response to fighting bacteria. Periodontal disease includes gingivitis and periodontitis. Gingivitis is a periodontal disease that only affects the gingiva, while periodontitis is a periodontal disease that affects

"Corresponding author: Amandia Dewi Permana Shita, Department of Biomedics, Faculty of Dentistry University of Jember, Indonesia. Jalan Kalimantan No.37, Jember, East Java, Indonesia, 68121. Phone: +62 813-3601-2472; Email: shita.drg.

fkg@unej.ac.id 
the deeper structures. This disease can cause bleeding gums, bad breath, tooth unsteadiness to lose teeth, disrupting the process of mastication. ${ }^{2}$

The cause of periodontal disease is multifactorial with bacteria in plaque as the primary cause. Among other periodontal pathogens, $P$. gingivalis is one of the critical pathogens in periodontal disease. ${ }^{2}$ This bacterium is anaerobic gram-negative bacteria, which has several virulence factors such as enzymes, lipopolysaccharides, fimbria, and outer protein membranes, which can destroy the periodontal tissues directly or indirectly by inducing inflammation. ${ }^{3}$ If the number of $P$. gingivalis colonies increases, periodontal tissue damage also increases. To prevent the rise of periodontal tissue damage, the growth of $P$. gingivalis must be inhibited. ${ }^{4}$

One way to inhibit the growth of microorganisms is by plaque control. Plaque control can be done mechanically by brushing teeth that depend on motivation. Individual motivation can decrease over time. Therefore, antiplaque chemicals are used to support mechanical plaque control. ${ }^{5}$

Plaque control is chemically carried out using a mouthwash containing antibacterial ingredients to clean areas that are not covered by toothbrushes. ${ }^{6}$ The use of non-herbal mouthwash for a long time causes allergic reactions or abnormalities in the oral cavity. For example, the use of chlorhexidine for a long time can cause a burning sensation, changes in taste perception and the appearance of stains on the teeth. ${ }^{7}$ Therefore, it is necessary to look for alternative ingredients from herbal ingredients to obtain minimal side effects. One of the natural ingredients currently developed as an antibacterial ingredient is namnam leaves (Cynometra cauliflora L.).

Namnam is the name of a fruiting tree species from the tribe of legumes (Leguminosae or Fabaceae) which often found in wet lowland areas. ${ }^{8}$ This plant is one of the rare species of native Indonesian plants. Also, this plant grows in Southeast Asia and India. ${ }^{9}$ This plant is often used by the fruit to be eaten fresh and leaves for diarrhoea medicine. ${ }^{10}$ Namnam leaves contain chemical compounds such as flavonoids, terpenoids, tannins, antibacterial saponins. ${ }^{11,12}$
Research on namnam leaves is very limited until now there has been no study that tested antibacterial extract of namnam leaves (Cynometra cauliflora L.) against $P$. gingivalis bacteria. Based on descriptions above, the purpose of this research was analysing the inhibition potential, and the highest inhibition concentration of namnam leaves extract on the growth of $P$. gingivalis.

\section{METHODS}

Type of this research is experimental laboratory. The research design is the post-test only control group design. This study used a total of 24 samples divided into 6 groups: $\mathrm{K}+$ (chlorhexidine gluconate $0.2 \%$ ) and namnam leaves extract group concentrations of $100,80,60,40$ and $20 \%$.

Research procedures include the preparation stage, inhibitory effect, inhibition zone measurement and data analysis. The preparation stage includes identification of $P$. gingivalis bacteria with gram staining, namnam leaves identification, tool sterilization using autoclave at $121^{\circ} \mathrm{C}$ for 30 minutes, namnam leaves extraction, making media and bacteria suspensions.

The extraction of namnam leaves is done by remaceration technique. Namnam leaves were washed with clean water then dried for 10 days, then ovened at $40^{\circ} \mathrm{C}$ for 4 days. Dried leaves are mashed with a blender and sieved with an 80 mesh sieve. ${ }^{13}$ Namnam leaves powder that has been sieved is taken 200 grams and put into a closed jar, then added $1000 \mathrm{ml}$ of methanol. The maceration stage was carried out for 48 hours while stirring every eight hours using a stirring rod and then it was regenerated for 48 hours. ${ }^{13,14}$ The filtrate was evaporated with a rotary evaporator at a temperature of $50^{\circ} \mathrm{C}$ to obtain concentrated extract with a concentration of $100 \%$. Then the extract was diluted to a concentration of 80,60 , 40 and $20 \%$. The dilution results were filtered using a syringe filter and inserted in the eppendorf tube. ${ }^{13}$

The next stage is the preparation of Brain Heart Infusion Broth (BHI-B) media and Brain Heart Infusion Agar (BHI-A). After making the media, followed by making a suspension of $P$. gingivalis bacteria. $P$. gingivalis used in this study 
were obtained from the Microbiology Laboratory of Faculty of Dentistry University of Jember. That bacteria has been identified as pure $P$. gingivalis ATCC 33277. One ointment of $P$. gingivalis from pure strains was put in a vacuum tube containing 2 $\mathrm{mL}$ media BHI-B. Vacuum tubes were inserted into the desicator and incubated at $37^{\circ} \mathrm{C}$ for 24 hours. Then dilution was done by adding sterile distilled water and homogenized with mixing vortex, until the absorbance reached 0.5 Mc Farland measured using a densitometer.

The next procedure is the antibacterial effect test stage. A total of $100 \mu \mathrm{L}$ of bacterial suspension was dripped on each culture medium. The suspension was flattened on the surface of the culture medium using sterile cotton swabs. On 24 pieces of disc paper, each of them was pressed with $13 \mu \mathrm{L}$ of namnam leaves extract with 5 concentrations and $0.2 \%$ Chlorhexidine using micropipette which was given a yellow tip and then waited for one minute to absorb. Paper discs are affixed to each surface of the culture media that has been inoculated with bacteria using sterile tweezers ${ }^{15}$. The petridish was inserted into the desicator and then incubated for 48 hours at $37^{\circ} \mathrm{C}$ in an upside down position to prevent water vapor from falling into the media so that it does not interfere with bacterial growth ${ }^{16}$.

The next procedure is the inhibition zone measurement stage using a digital shear term with $0.01 \mathrm{~mm}$ accuracy and recorded. The method of measuring the diameter of the inhibitory zone is by measuring the length diameter (a) plus the short diameter (b) then dividing it into $2^{17}$ (Figure 1).

The results of the research data were Saphiro-Wilk and Levene statistical test using Statistical Product and Service Solution (SPSS) software. The resulting data is normally distributed and homogeneous, so that the One-Way ANOVA parametric statistical test can be carried out then

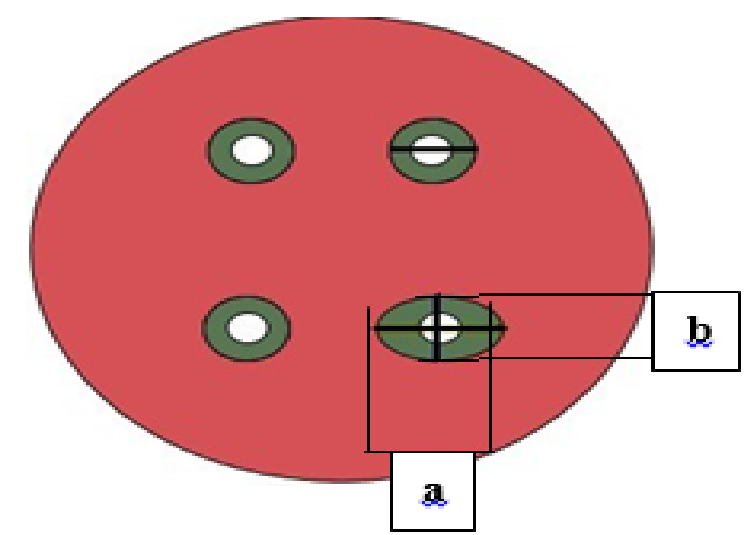

Figure 1. Inhibitory zone measurement

followed by the Tukey-HSD statistical test. All data tests used a 95\% significance level $(\alpha=0.05)$.

\section{RESULTS}

The results of the research on the inhibitory power of namnam leaves extract (Cynometra cauliflora L.) on $P$. gingivalis growth obtained inhibitory zones around disc paper in all research groups. The results of the research data are presented in Table 1.

Table 1. The inhibitory zone diameter of namnam leaves extract on $P$. gingivalis growth

\begin{tabular}{cc}
\hline Groups & Inhibitory zone diameter $(\mathrm{X} \pm \mathrm{SD})(\mathrm{mm})$ \\
\hline $\mathrm{K}+$ & $13.61 \pm 1.71$ \\
$100 \%$ & $11.43 \pm 0.66$ \\
$80 \%$ & $11.05 \pm 0.84$ \\
$60 \%$ & $10.62 \pm 0.64$ \\
$40 \%$ & $10.03 \pm 1.32$ \\
$20 \%$ & $8.59 \pm 1.03$ \\
\hline
\end{tabular}

Note: X: Mean; SD: Standard deviation; K+: Positive control group (Chlorhexidine gluconate $2 \%$ ); *significant difference

The results of the One Way Anova test showed significant differences between all study groups $(p<0.05)$. Furthermore, the Tukey-HSD test was conducted to find out the differences between the 2 study groups (Table 2 ).

Table 2. The Tukey-HSD test of the inhibitory zone diameter of namnam leaves extract on $P$. gingivalis growth

\begin{tabular}{ccccccc}
\multirow{2}{*}{ Groups } & \multicolumn{7}{c}{ P value } \\
\cline { 2 - 7 } & $\mathrm{K}+$ & $100 \%$ & $80 \%$ & $60 \%$ & $40 \%$ & $20 \%$ \\
\hline $\mathrm{K}+$ & - & 0.105 & $0.041^{*}$ & $0.013^{*}$ & $0.003^{*}$ & $0.000^{*}$ \\
$100 \%$ & 0.105 & - & 0.996 & 0.897 & 0.491 & $0.019^{*}$ \\
$80 \%$ & $0.041^{*}$ & 0.996 & - & 0.993 & 0.777 & 0.052 \\
$60 \%$ & $0.013^{*}$ & 0.897 & 0.993 & - & 0.972 & 0.146 \\
$40 \%$ & $0.003^{*}$ & 0.491 & 0.777 & 0.972 & - & 0.459 \\
$20 \%$ & $0.000^{*}$ & $0.019^{*}$ & 0.052 & 0.146 & 0.459 & - \\
\hline
\end{tabular}


The results of the Tukey-HSD test in Table 2 showed a significant difference between the $K$ + group with 80,60, 40 and 20\% group; and the $100 \%$ with $20 \%$ group $(p<0.05)$. Whereas in the other groups there were no significant differences ( $p>0.05$ ), which means that the diameter of the inhibitory zone between the two groups was almost the same.

\section{DISCUSSION}

This study was aimed to determine the inhibitory power of namnam leaves extract (Cynometra cauliflora L) on the growth of $P$. gingivalis. Namnam leaves extract made using remaceration method. Based on previous research, remaceration extraction method yields the highest extract yield compared to other methods. This is because the contact time between the solvent and simplicia in the remaceration method is longer than other methods such as percolation, maceration and reperolation. ${ }^{18}$

The solvent used in the remaceration process is methanol. The use of methanol in this study because methanol is able to dissolve more phytochemical compounds than other solvents. Methanol has a polar group that is stronger than nonpolar groups, so it is able to extract more bioactive components that have higher polar properties such as saponins, quinones, flavonoids and tannins. This can be seen from the chemical structure of methanol containing hydroxyl (polar) and carbon (nonpolar) groups ${ }^{19}$.

The antibacterial power test method used in this study is disc diffusion method. The media to be tested is placed in a desiccator with a reversed condition. This can prevent droplets of water vapor from falling onto the medium that has been planted with bacteria, these droplets can affect the final result of incubation ${ }^{20}$.

The results showed that all namnam leaves extract groups had inhibitory power on $P$. gingivalis growth. The diameter of inhibition zone of namnam leaves extract concentrations of $100 \%, 80 \%, 60 \%$, $40 \%$ and $20 \%$ were $11.43 \mathrm{~mm}, 11.05 \mathrm{~mm}, 10.62 \mathrm{~mm}$, $10.03 \mathrm{~mm}$ and $8.59 \mathrm{~mm}$ respectively. This shows an increase in the diameter of the inhibitory zone as the concentration of extract increases, so that the namnam leaves extract $100 \%$ concentration has the greatest inhibitory ability than other concentrations. This is presumably because the greater the concentration of an extract, the higher the content of antibacterial compounds so that the antibacterial ability is increasing. When compared with $0.2 \%$ chlorhexidine gluconat, namnam leaves extract 100\% concentration has a smaller inhibitory zone diameter. Based on the Tukey-HSD test, it was found that $p=0.105$ showed that there were no significant differences between the groups so that it could be said that namnam leaves extract concentration of $100 \%$ and $0.2 \%$ chlorhexidine gluconate had almost the same ability in inhibiting the growth of $P$. gingivalis. This study proved that namnam leaves extract was able to inhibit the growth of $P$. gingivalis. This is consistent with previous research which states that namnam leaves extract has antibacterial activity ${ }^{21}$. The results of this research are in accordance with other research which states that namnam leaves extract has an antibacterial effect, but in Staphylococcus epidermidis and Pseudomonas aeuruginosa bacteria ${ }^{22}$. Other researcher also stated that the methanol extract of namnam leaves has antibacterial activity, namely in Staphylococcus aureus but not in E. coli ${ }^{13}$. The antibacterial properties found in namnam leaves extract are tannins, flavonoids, triterpenoids, saponins and quinones 13, 23, 24. Each of these active substances has a different mechanism as an antibacterial.

Flavonoids work as antibacterials by inhibiting the formation of DNA and RNA which play a role in hydrogen bonds so that nucleic acid bases accumulate and the permeability of cell walls of bacteria, lysosomes and microsomes were damage ${ }^{25}$. Flavonoids can also form complex compounds with extracellular proteins, causing damage to bacterial cell membranes and followed by the release of intracellular compounds ${ }^{26}$. In addition, flavonoids are also able to inhibit cytochrome $C$ reductase so that the use of oxygen in bacteria will be inhibited ${ }^{27}$.

Tannin compounds will damage bacterial cell membranes by changing permeability and disrupt the power of the cytoplasmic membrane protons that dissolve fat. In lower concentrations, tannins will activate enzyme systems in bacterial cells ${ }^{13}$. While saponins will bind to the cytoplasmic membrane so that the surface tension will decrease and cause the release of intracellular 
compounds ${ }^{27}$. Other compounds, namely quinone are antibacterial by forming irreversible complexes with nucleophilic amino acids so that cell proteins cannot function normally ${ }^{28}$.

Antibacterial power strength can be divided into three, namely the diameter of the inhibitory zone of less than $10 \mathrm{~mm}$ is categorized as weak, the diameter of the inhibitory zone $10-20 \mathrm{~mm}$ is categorized as moderate and the diameter of the inhibitory zone of more than $20 \mathrm{~mm}$ is categorized as strong ${ }^{29}$. Therefore, the antibacterial power of namnam leaves extract on the growth of $P$. gingivalis can be divided into two categories, namely namnam leaves extract $20 \%$ concentration was included in the weak category, while namnam leaves extract concentration of $100 \%, 80 \%, 60 \%$, $40 \%$ in the medium category. The difference in inhibitory zone size and antibacterial strength is influenced by several things, including the sensitivity level of the test organism, the speed of diffusion of antibacterial compounds and the concentration of antibacterial compounds ${ }^{30}$. This study is still limited to testing the antibacterial effects, especially P.gingivalis bacteria in namnam leaves extract. This article is still in the level of preliminary research, only the value of inhibition studied with no MIC value, so this research needs to be continued. Further research on toxicity and biocompatibility tests, as well as in vivo research on namnam leaves extract is also needed before this extract can be used in humans.

This study still requires further research to determine the Minimum Inhibitory Concentration (MIC) of namnam leaves extract against P.gingivalis. Further research needs to be done to test the other potential of namnam leaves extract for example as an antifungal, antioxidant, anticancer and antidiabetic.

\section{CONCLUSION}

Namnam leaves extract can inhibit the growth of P. gingivalis. $100 \%$ of namnam leaves extract has the highest antibacterial inhibition zone.

\section{REFERENCES}

1. Directorate General of Health Care Development. Rencana Program Pelayanan
Kesehatan Gigi dan Mulut. Jakarta: Ministry of Health of Republic of Indonesia; 2012.

2. Newman M, Takei H, Klokkevold P, Carranza F. Carranza's Clinical Periodontology. $12^{\text {th }}$ ed. Philadelphia: Saunders-Elsevier; 2015.

3. How KY, Song KP, Chan KG. Porphyromonas gingivalis: An Overview of Periodontopathic Pathogen below the Gum Line. Front Microbiol. 7: 53. DOI: $10.3389 / \mathrm{fmicb} .2016 .00053$

4. Jandik KA, Belanger M, Low SL, Dorn BR, Yang MC, Progulske-Fox A. Invasive Differences among Strains of Porphyromonas gingivalis From Healthy and Diseased Periodontal Sites. J Periodontal Res. 2008; 43(5): 524-30. DOI: 10.1111/j.1600-0765.2007.01064.x

5. Menon L, Ramamurthy J. New Vistas in Plaque Control. IOSR J Dent Med Sci. 2014; 13(3): 648. DOI: $10.9790 / 0853-13356468$

6. Santana W, Thahar B, Mardiati E, Salim J. The effect of alcohol-containing mouthwash and alcohol-free mouthwash towards the power chains force decay. Padjadjaran J Dent. 2017; 29(3): 196-203. DOI: 10.24198/pjd. vol29no3.14476

7. Kaur P, Singh H, Khatri A, Aulakh KS. Evaluation and Comparison of Short Term Side Effects of $0,2 \%$ and $0,12 \%$ Chlorhexidine Mouthwash. J Adv Med Dent Sci Res. 2015; 3(3): 26-8.

8. Purwantoro RS, Satyanti A, Yuswandi AY. Namnam (Cynometra cauliflora L.) di Kebun raya Bogor: Tingkat Kejadian Buah Rendah dan Studi Laju Perkembangan Buah. 7th Basic Science National Seminar Proceeding; 2010 February 20; Malang, Indonesia. Malang: Brawijaya University; 2010.

9. Verheij EWM, Coronel RE. PROSEA = Sumber Daya Nabati Asia Tenggara. 2, Buah-buahan yang dapat Dimakan. Jakarta: Gramedia Pustaka Utama; 1997.

10. Tiranda R, Suseno AD. Informasi Singkat Benih Cynometra cauliflora L. Informasi Singkat Benih. 2013; 170: 1-2.

11. Abd Aziz AF, Iqbal M. Antioxidant Activity and Phytochemical Composition of Cynometra cauliflora. J Exp Integr Med. 2013; 3(4): 33741. DOI: $10.5455 /$ jeim.250813.or.086

12. Adawiah, Sukandar D, Muawanah A. Aktivitas Antioksidan dan Kandungan Komponen Bioaktif Sari Buah Namnam. J Kim Valensi J Penelit 
Pengembang Ilmu Kim. 2015; 1(2): 130-6. DOI: 10.15408/jkv.v0i0.3155

13. Sumarlin LO, Suprayogi A, Rahminiwati M, Tjahja A, Sukandar D. Bioaktivitas Ekstrak Metanol Daun Namnam Serta Kombinasinya dengan Madu Trigona. J Tek Industri Pangan. 2015; 26(2): 144-54. DOI: $10.6066 /$ jtip.2015.26.2.144

14. Puspitasari AD, Proyogo LS. Perbandingan Metode Ekstraksi Maserasi dan Sokletasi terhadap Kadar Fenolik Total Ekstrak Metanol Daun Kersan (Muntingia calabura). Cendekia Eksata. 2017; 2(1): 1-8.

15. Fatimah IA. Pengaruh Ekstrak Flavonoid Rendah Nikotin Limbah Daun Tembakau Kasturi (Nicotiana tabaccum L.) terhadap Pertumbuhan Mikroba Rongga Mulut [minor thesis]. Jember: University of Jember; 2016.

16. Patel JB, Cockeril III FR, Bradford PA, Eliopoulus GM, Hindler JA, Jenkins SG, et al. Performance Standards for Antimicrobial Susceptibility Testing; Twenty-Fifth Informational Supplement. Clin Labor Standard Institute. 2015; 35(3): M100-S25.

17. Rosidah AN. Daya Antibakteri Ekstrak Daun Kendali (Hippobroma longiflora [L] G. Don) terhadap Pertumbuhan Streptococcus mutans [minor thesis]. Jember: University of Jember; 2014.

18. Pratiwi E. Perbandingan Metode Maserasi, Remaserasi, Perkolasi dan Reperkolasi dalam Eksraksi Senyawa Aktif Androglapholide dari Tanaman Sambiloto (Andrographis paniculata (burm.f) Nees) [minor thesis]. Bogor: Bogor Agricultural University; 2010.

19. Romadanu R, Hanggita S, Lestari SD. Pengujian Aktivitas Antioksidan Ekstrak Bunga Lotus (Nelumbo nucifera). J Fishtech. 2014; 3(1): 1-7.

20. Putra IMAS. Uji Aktivitas Antibakteri Ekstrak Etanol Daun Sirsak (Annonae muricata L.) dengan Metode Difusi Agar Cakram Terhadap Escherichia coli. Medicamento. 2015; 1(1): 15-19.
21. Maharani T, Sukandar D, Hermanto S. Karakterisasi Senyawa Hasil Isolasi dari Ekstrak Etil Asetat Daun Namnam (Cynometra cauliflora L.) yang Memiliki Aktivitas Antibakteri. J Kim Valensi. 2016; 2(1): 55-62. DOI: $10.15408 / \mathrm{jkv} . \mathrm{v} 2 \mathrm{i1} .3084$

22. Waty F. Aktivitas Antibakteri Ekstrak Daun Namnam (Cynometra cauliflora L.) Terhadap Staphylococcus epidermidis dan Pseudomonas aeruginosa [minor thesis]. Yogyakarta: Atma Jaya University; 2016.

23. Sukandar D, Amelia ER. Karakterisasi Senyawa Aktif Antioksidan dan Antibakteri Dalam Ekstrak Etanol Namnam (Cynometra cauliflora L.). J Kim Valensi. 2013; 3(1): 35-40. DOI: 10.15408/jkv.v3i1.327

24. Abd Aziz AF, Iqbal M. Antioxidant Activity and Phytochemical Composition of Cynometra cauliflora. J Exp Integr Med. 2013; 3(4): 33741. DOI: $10.5455 /$ jeim. $250813.0 r .086$

25. Cushnie TP, Lamb AJ. Antimicrobial Activity of Flavonoids. Int $\mathrm{J}$ Antimicrob Agents. 2005; 26(5): 343-56. DOI: 10.1016/j. ijantimicag.2005.09.002

26. Ngajow M, Abidjulu J, Kamu VS. Pengaruh Antibakteri Ekstrak Kulit Batang Matoa (Pometia pinnata) Terhadap Bakteri Staphylococcus aureus secara In Vitro. J MIPA UNSRAT Online. 2013; 2(2): 128-32. DOI: 10.35799/jm.2.2.2013.3121

27. Cavalieri SJ. Manual of Antimicrobial Susceptibility Testing. Washington DC: American Society for Microbiology; 2009.

28. Pandey AK, Kumar S. Perspective on Plant Products as Antimicrobial Agents: A Review. Pharmacologia. 2013; 4(7): 469-80. DOI: 10.5567/pharmacologia2013.469.480

29. Davis WW, Stout TR. Disc Plate Methods of Microbiology Antibiotic assay. Appl Microbiol. 1971; 22(4): 659-65.

30. Prescott LM, Harley JP, Klein DA. Microbiology. $6^{\text {th }}$ ed. New York: McGraw-Hill Higher Education; 2005. 